\title{
Pengaruh Malnutrisi dan Faktor lainnya terhadap kejadian Wound Dehiscence pada Pembedahan Abdominal Anak pada Periode Perioperatif
}

\author{
Tinuk Agung Meilany,* Alexandra,** Ariono Arianto,** Qamarrudin Bausat,** Endang \\ $S K$,** Joedo Prihartono,*** Damayanti R Sjarif**** \\ *SMF IKA RSAB Harapan Kita Jakarta \\ **Bagian Bedah Anak RSAB Harapan Kita Jakarta. *** Bagian IKK FKUI RSCM Jakarta \\ **** Departemen Ilmu Kesehatan Anak FKUI RSCM Jakarta
}

\begin{abstract}
Latar belakang. Wound dehiscence adalah salah satu komplikasi bedah abdominal yang jarang ditemui, namun sering menyebabkan kematian, meningkatkan lama rawat, biaya, dan risiko infeksi berat dengan akibat kematian. Malnutrisi dianggap sebagai salah satu faktor yang berkontribusi terhadap kejadian dehiscence tersebut. Tujuan. Menilai angka kejadian dehiscence bedah mayor pada anak yang berbeda status gizi, risiko relatif serta faktor lain yang mempengaruhi risiko dehiscence.

Metode. Penelitian kohort prospektif pada 262 kasus bedah abdominal mayor pada anak. Pasien yang memenuhi kriteria dibagi 2 kelompok yaitu menderita malnutrisi dan tidak. Tata laksana dilakukan sesuai standar Bagian Bedah Anak RSAB Harapan Kita. Pengamatan dilakukan selama periode perioperatif sampai pulang dari rumah sakit. Dihitung angka kejadian, risiko relatif, dan faktor atribusi dehiscence. Pengolahan data dan analisis menggunakan SPSS versi 11.5 dan Open Epi

Hasil. Angka kejadian dehiscence 2,7\% (7/262), satu pasien gizi baik (0,8\%), gizi kurang 2/7(1,7\%), gizi buruk 4/4(100\%). Terjadi pada hari kelima pasca operasi (kisaran 3-7hari). Lama rawat 25 hari (14-73) vs 10 hari (1-10) tidak dehiscence. Meninggal dunia 1/7dehiscence. Risiko dehiscence meningkat secara bermakna pada gizi buruk $v$ sizi baik (RR136, IK95\% 19,3-958,6, $\mathrm{p}=0,000)$. Hipoalbumin $v$ s normal (RR23,6, IK95\% 5,8-95,4, p=0,000). Anemia vs normal (RR18,6, IK95\% CI3.7-91.9, p=0,000). Sepsis vs normal (RR10,7, IK95\% 2,5-45,5, p=0,000). Faktor atribusi dehiscence 99,3\% karena gizi buruk, hipoalbumin $96,6 \%$, sepsis $90,7 \%$, gizi kurang $59 \%$.

Kesimpulan. Status gizi buruk, hipoalbumin, dan sepsis berperan hampir seratus persen terhadap kejadian dehiscence pada anak. Saran, perlu dilakukan skoring risiko tinggi dehiscence pada anak yang akan menjalani bedah mayor. Sari Pediatri 2012;14(2):110-6.
\end{abstract}

Kata kunci: Wound dehiscence, gizi buruk, risiko relatif

\footnotetext{
Alamat korespondensi:

Dr. Tinuk Agung Meilany, Sp.A. Bagian Ilmu Kesehatan Anak, KK Nutrisi dan Penyakit Metabolik Anak RSAB Harapan Kita Jl. Let Jen S

Parman kav 87 Jakarta Barat. E-mail: tameilany@gmail.com
} 


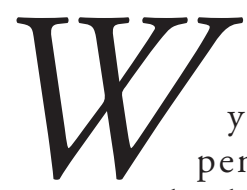

ound dehiscence adalah salah satu komplikasi luka operasi yang terinfeksi. Komplikasi lain penyembuhan luka dipindah; yang lambat, morbiditas dan mortalitas yang meningkat, serta lama rawat yang berkepanjangan. ${ }^{1}$ Penyembuhan luka sangat buruk dan luka terbuka kembali. Luka menetap, meluas, dan penyembuhan menjadi lebih lama serta risiko infeksi meningkat. Kata lain dari dehiscence adalah kegagalan mekanik penyembuhan luka insisi. Insisi pada operasi menstimulasi proses penyembuhan yang melalui empat fase berbeda dan berkesinambungan yaitu hemostasis, inflamasi, proliferasi, dan maturasi. Selama hemostasis, trombosit beragregasi, zat pembeku darah mengala mi aktivasi dan degranulasi. Bekuan darah didegradasi, pembuluh kapiler melebar, cairan memasuki sisi luka, dan aktivasi kaskade komplemen. Makrofag, sel yang lisis dan neutrofil merupakan sediaan sitokin dan faktor pertumbuhan yang esensial untuk penyembuhan luka. Pada fase proliferasi terjadi pembentukan jaringan granulasi yang dimulai pada hari ketiga pasca operasi dan berakhir beberapa minggu. Terpenting pada fase tersebut fibroblas bergerak ke arah luka dan merespon sintesis kolagen. Fase maturasi dimulai pada hari ketujuh pasca operasi dilanjutkan deposisi jaringan kolagen dan remodeling untuk meningkatkan kekuatan regangan luka. ${ }^{2-3}$

Malnutrisi sering dihubungkan dengan komplikasi yang terjadi pada tindakan pembedahan. Meskipun masih sulit menyatakan hubungan penyebabnya, telah diketahui bahwa malnutrisi dapat menghambat penyembuhan luka operasi, daya tahan tubuh (imunokompetens), penurunan fungsi otot jantung, dan respiratori. Lebih jauh lagi pasien malnutrisi akan mempunyai risiko morbiditas lebih tinggi sebanding dengan lama rawat yang lebih panjang, apabila dibandingkan dengan pasien bergizi baik. ${ }^{4}$

Nutrisi yang optimum merupakan kunci utama untuk pemeliharaan seluruh fase penyembuhan luka. Terdapat dua proses yang dapat melengkapi penyembuhan luka yaitu aktivasi respon stres pada fase akut terhadap luka serta malnutrisi energi dan protein yang terjadi. Pemberian dukungan nutrisi pada periode perioperatif tersebut dapat menurunkan komplikasi terutama infeksi berat pada pasien malnutrisi.

Insidens WD berkisar antara 0,2\%-3\% dan berhubungan pada kematian dengan rerata kejadian $8 \%-45 \%$. Kasus WD terbanyakan terjadi pada anak yang menjalani pembedahan mayor laparatomi karena invaginasi, typhoid perforasi, anastomosis usus halus ataupun usus besar atau tutup kolostomi pada atresia ani, prosedur Pullthrough pada Morbus Hirscsprung.

Faktor risiko yang mempengaruhi dehiscence pasca laparatomi adalah anak dengan gizi kurang dan atau gizi buruk, hipoalbuminemia, infeksi berat (sepsis). Faktor lain disebutkan adalah obesitas, jenis kelamin laki-laki, usia terlalu muda (neonatus atau bayi), operasi darurat, serta bentuk atau model insisi. ${ }^{4}$

Tujuan umum penelitian kami untuk membuktikan hipotesis bahwa bedah abdominal pada anak dengan malnutrisi berat lebih meningkatkan risiko terjadi dehiscence dibandingkan dengan anak yang satus gizi baik. Penelitian dilakukan dengan mengidentifikasi kejadian dehiscence pada pasien anak malnutrisi dan tidak malnutrisi yang mengalami bedah abdomen mayor dengan atau tanpa faktor-faktor risiko yang mempengaruhi kejadian dehiscence. Sedangkan tujuan khusus untuk mendapatkan insidens dehiscence, memperoleh kekuatan hubungan antara faktorfaktor risiko kadar albumin, infeksi, tipe operasi, jenis kelamin terhadap kejadian dehiscence pada kedua kelompok melalui studi kohort prospektif. Manfaat penelitian yaitu menyusun persiapan operasi dan perawatan nutrisi perioperatif yang lebih baik ketika pembedahan laparatomi, terutama pada anak malnutrisi. Hasil penelitian kami merupakan penelitian pendahuluan untuk penelitian lanjutan menentukan sistem skoring pada perawatan nutrisi perioperatif pada anak yang akan menjalani operasi mayor abdomen, upaya pencegahan kejadian dehiscence, dan menurunkan angka kematian akibat pembedahan pada anak.

\section{Metode}

Penelitian kohort prospektif dilakukan di Rumah Sakit Anak dan Bunda Harapan Kita Jakarta Bagian Bedah Anak pada Januari 2005 sampai Desember 2010. Sampel penelitian adalah kasus bedah mayor abdominal, baik pada keadaan terencana maupun darurat serta memenuhi kriteria inklusi. Kriteria inklusi adalah menyetujui dikutsertakan dalam penelitian, belum pernah mengalami dehiscence, kasus bedah abdominal mayor yaitu perforasi usus karena typhoid, 
appendisitis, invaginasi, morbus hirschsprung, atresia ani, atresia oesophagus, atresia ileum, stenosis pada usus halus ataupun usus besar. Semua pasien di tata laksana sesuai Standar Perawatan Bedah anak yang dilakukan oleh Tim Bedah Anak yang terdiri dari Spesialis Bedah anak, Spesialis Anak, Spesialis Anestesi, paramedis, yang dilengkapi dengan perawatan nutrisi perioperatif, serta tim perawatan luka. Apabila didapatkan masalah pediatrik khusus selama perawatan, dilakukan konsultasi pediatrik pada konsultan anak terkait di RS bersangkutan. Kasus dengan riwayat dehiscence sebelumnya dan pasien yang tidak memenuhi persyaratan pembiusan tidak diikutsertakan. Data jenis kelamin, umur, status gizi, anemia, hipoalbumin, sepsis, tipe operasi darurat atau elektif, klasifikasi ASA, tipe insisi, komplikasi pasca operasi seperti timbul tidaknya dehiscence, sepsis, kematian dalam perawatan, serta lama rawat diikutsertakan. Variabel tergantung adalah dehiscence dan variabel bebas adalah status gizi, infeksi berat atau sepsis, kadar albumin, tipe operasi, umur, dan jenis kelamin.

Sampel dibagi dua yaitu kelompok malnutrisi terdiri dari gizi buruk dan gizi kurang, serta kelompok gizi baik. Penentuan besar sampel setiap kelompok dihitung menggunakan rumus Open Epi dengan hasil jumlah sampel pada masing-masing kelompok 117 dan total 234. Pada penelitian kami terdapat 262 kasus dan diikutsertakan seluruhnya. Pengolahan data menggunakan SPSS seri 11.5 dan penghitungan dengan program Open Epi. Rencana analisis penelitian adalah uji normalitas terhadap sosiodemografi yaitu umur, jenis kelamin, dan jenis operasi. Menghitung angka kejadian dehiscence, menentukan signifikansi dengan $\mathrm{p}<0,05$, risiko relatif, dan atributable risk. Apabila terdapat ketidak-setaraan faktor, dilakukan analisis regresi multivariat

\section{Hasil}

Karakteristik kasus gizi buruk, gizi kurang, maupun gizi baik dalam penelitian kami memiliki distribusi normal dan tidak berbeda bermakna apabila ditinjau dari perbedaan jenis kelamin, maupun tipe kedaruratan operasi, kecuali pada kelompok umur terdapat perbedaan sebaran (Tabel 1).

Angka kejadian dehiscence 2,7\% (7/262 kasus). Satu kasus $(0,8 \%)$ dengan status gizi baik, 2 kasus $(1,8 \%)$ dengan gizi kurang, dan 4 kasus (100\%) dengan gizi buruk. Rerata waktu hari ke-5 pasca operasi (kisaran 3-7), dan tidak didapatkan kejadian dehiscence berulang.

Rerata lama rawat secara bermakna menjadi lebih panjang pada dehiscence dibandingkan yang tidak dehiscence ( $\mathrm{p}<0,001$ ) yaitu 25 hari (14-73 hari), dibandingkan rerata 10 hari (1-10 hari). Pasien meninggal selama perawatan 1 anak, berumur 1.68 tahun, kasus emergensi pada ileus obstruksi, peritonitis, atresia ani, telah kolostomi saat usia 1 hari. Pasca operasi mengalami sepsis karena kandida, dehiscence pada hari ke 4 pasca operasi. Pasien meninggal pada hari ke 16 pasca operasi.

Kejadian dehiscence meningkat pada kasus dengan status gizi buruk, hipoalbumin, sepsis, dan anemia. Sedangkan pada kasus dengan status gizi kurang, jenis kedaruratan operasi dan perbedaan jenis kelamin mempengaruhi tetapi tidak bermakna. Pasien gizi buruk dibandingkan gizi baik, mempunyai risiko peningkatan 136 kali lipat mengalami dehiscence, status gizi kurang hanya 2.23 kali lipat, Hipoalbuminemia dibandingkan normal meningkat 23 kali lipat. Anemia dibandingkan tidak anemia meningkatkan risiko 18.63 kali lipat. Sepsis meningkatkan risiko 10.7 kali lipat (Tabel 2.).

Di antara faktor-faktor yang bermakna penyebab

Tabel 1: Sebaran subyek menurut faktor risiko dan status gizi

\begin{tabular}{|c|c|c|c|c|c|c|}
\hline \multirow[t]{2}{*}{ Faktor risiko } & & \multicolumn{3}{|c|}{ Status gizi } & \multirow{2}{*}{$\begin{array}{c}\text { Jumlah } \\
\mathrm{n}\end{array}$} & \multirow[b]{2}{*}{$\mathrm{p}$} \\
\hline & & Gizi baik & Gizi kurang \# & Gizi buruk \# & & \\
\hline \multirow[t]{2}{*}{ Jenis kelamin } & Laki-laki & 89 & 70 & 3 & 162 & 0,335 \\
\hline & Perempuan & 48 & 51 & 1 & 100 & \\
\hline \multirow[t]{2}{*}{ Umur (tahun) } & $>1$ & 37 & 70 & 3 & 110 & 0,000 \\
\hline & $0-1$ & 100 & 51 & 1 & 152 & \\
\hline \multirow[t]{2}{*}{ Tipe operasi } & Elektif & 114 & 101 & 4 & 219 & 0,996 \\
\hline & Emergensi & 23 & 20 & 0 & 43 & \\
\hline
\end{tabular}

Ket: \# dilakukan penggabungan dalam uji kemaknaan 
dehiscence, yaitu status gizi (digabung antara gizi kurang dan buruk), status albumin, anemia, dan infeksi dilakukan uji logistik regresi dan faktor infeksi berat dan anemia paling berperan (Tabel 3).

Faktor atribusi gizi buruk penyebab dehiscence $99,3 \%$, dengan kata lain dehiscence terjadi karena atribusi dari gizi buruk, dan 96,6\% karena faktor hipoalbumin, serta $90,7 \%$ karena faktor sepsis, gizi kurang 59\%, dan anemia 43,75\% (Tabel 4).
Tabel 4. Attributable risk pada wound dehiscence

\begin{tabular}{lc}
\hline Kasus & Persentase risiko atribusi \\
\hline Status gizi buruk & 99,3 \\
Status gizi kurang & 59 \\
Hipoalbumin & 96,6 \\
Sepsis & 90,7 \\
Anemia & 43,75 \\
\hline
\end{tabular}

Tabel 2: Sebaran subyek menurut faktor risiko dan luka dehiscence (uji mutlak Fisher)

\begin{tabular}{|c|c|c|c|c|c|c|}
\hline \multirow{2}{*}{ Faktor risiko } & \multicolumn{2}{|c|}{ Dehiscence } & \multirow[b]{2}{*}{$\mathrm{p}$} & \multirow{2}{*}{$\mathrm{RR}$} & \multicolumn{2}{|c|}{$95 \%$ IK } \\
\hline & $\mathrm{Ya}$ & Tidak & & & Low & High \\
\hline \multicolumn{7}{|l|}{ Jenis kelamin } \\
\hline Perempuan & 2 & 98 & 0,712 & 1,54 & 0,31 & 7,80 \\
\hline Laki-laki & 5 & 157 & & & & \\
\hline \multicolumn{7}{|c|}{ Kelompok umur (tahun) } \\
\hline $0-1$ & 3 & 149 & 0,458 & 0,54 & 0,12 & 2,38 \\
\hline$>1$ & 4 & 106 & & & & \\
\hline \multicolumn{7}{|l|}{ Tipe operasi } \\
\hline Emergensi & 1 & 42 & 1,000 & 0,85 & 0,10 & 6,87 \\
\hline Elektif & 6 & 213 & & & & \\
\hline \multicolumn{7}{|l|}{ Status gizi } \\
\hline Buruk & 4 & 0 & 0,000 & 136,0 & 19,30 & 958,6 \\
\hline Baik & 1 & 135 & & & & \\
\hline \multicolumn{7}{|l|}{ Status gizi } \\
\hline Kurang & 2 & 120 & 0,604 & 2,23 & 0,20 & 24,28 \\
\hline Baik & 1 & 135 & & & & \\
\hline \multicolumn{7}{|l|}{ Status gizi gabungan } \\
\hline Buruk/kurang & 6 & 120 & 0,058 & 6,48 & 0,79 & 53,05 \\
\hline Baik & 1 & 135 & & & & \\
\hline \multicolumn{7}{|l|}{ Status albumin } \\
\hline Terganggu & 4 & 10 & 0,000 & 23,62 & 5,84 & 95,47 \\
\hline Normal & 3 & 245 & & & & \\
\hline \multicolumn{7}{|l|}{ Status anemia } \\
\hline Ada & 5 & 26 & 0,000 & 18,63 & 3,77 & 91,94 \\
\hline Tidak & 2 & 229 & & & & \\
\hline \multicolumn{7}{|l|}{ Status infeksi } \\
\hline Ada & 4 & 25 & 0,003 & 10,71 & 2,52 & 45,5 \\
\hline Tidak & 3 & 230 & & & & \\
\hline
\end{tabular}

Tabel 3. Analisis logistik regresi untuk luka dehiscence secara backward stepwise

\begin{tabular}{lcccc}
\hline Variabel risiko & \multirow{2}{*}{$\mathrm{p}$} & $\mathrm{R}$ & \multicolumn{2}{c}{ IK95\% } \\
\cline { 5 - 5 } & & & Low & High \\
\hline Status gizi & 0,022 & 16,41 & 1,076 & 147,49 \\
Anemia & 0,025 & 11,87 & 1,375 & 130,58 \\
Hipoalbuminemia & 0,015 & 26,76 & 1,776 & 208,6 \\
\hline
\end{tabular}

Keterangan: Variabel bebas yang dilibatkan : Umur, status gizi, hipoalbumin, anemia, infeksi 


\section{Pembahasan}

Kami mendapatkan angka kejadian dehiscence 2,7\% (7/262) kasus pasca operasi bedah mayor selama periode 2005-2010. Kejadian tersebut menunjukkan kecenderungan peningkatan kejadian apabila dibandingkan temuan sebelumnya di beberapa senter. Penelitian Waldhausen ${ }^{6}$ tahun 2000 menemukan

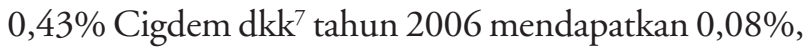
sedangkan Ramshorst dkk ${ }^{4}$ tahun 2009 memperoleh 0,6\% (12/1942 pasien). Angka kejadian dehiscence kecil namun berhubungan dengan angka kematian yang tinggi 8\%-45\%. Terdapat 1 dari 262 peserta penelitian $(3,8 \%)$ meninggal dunia dan menjadi tinggi apabila dibandingkan dengan kejadian dehiscence yaitu 14,3\% (1/ 7 kasus ).

Faktor risiko yang meningkatkan dehiscence pada anak telah beberapa kali diteliti yakni umur kurang dari 1 tahun, luka operasi yang terinfeksi, insisi median, operasi emergensi. ${ }^{4}$ Penelitian kami menetapkan faktor risiko pada variabel tergantung adalah status gizi buruk dan gizi kurang, hipoalbumin, infeksi, umur, jenis kelamin. Faktor risiko yang bermakna adalah gizi buruk, hipoalbuminemia, infeksi berat. Hubungan dehiscence yang kuat dengan faktor berpengaruh ditunjukkan dengan risiko relatif yang besar. Temuan kami, status gizi buruk berisiko meningkat 136 kali lipat, hipoalbumin 23,6 kali lipat, anemia 18,6 kali lipat, infeksi berat/ sepsis 10,7 kali lipat. Peningkatan tajam terjadi pada status gizi buruk. Namun apabila status gizi buruk dan gizi kurang digabungkan dan dibandingkan dengan gizi baik (malnutrisi vs tidak malnutrisi), maka perbedaan tidak bermakna. Hal tersebut menunjukkan, apabila anak berstatus gizi buruk baru bermakna melipat gandakan risiko terjadi dehiscence. Gizi buruk, menyebabkan gangguan proses penyembuhan luka melalui proses inflamasi yang berkepanjangan dan menyebabkan waktu penyembuhan lebih lama. Hipoksia jaringan yang terjadi karena keadaan anemia dan faktor infeksi juga memperkuat berlangsungnya proses inflamasi kronis. Apabila keadaan di atas diikuti dengan pemenuhan nutrisi yang tidak adekuat, karena nutrisi merupakan bahan kebutuhan dasar bagi fungsi, kelangsungan hidup, integritas dan pemulihan sel, maka akan menurunkan kualitas penyembuhan luka dan memerlukan waktu penyembuhan lebih panjang. Optimalisasi nutrisi pada semua jenis operasi penting untuk persiapan operasi dan akan secara langsung berdampak pada proses penyembuhan luka dan peyambungan jaringan viseral sampai kulit. ${ }^{8,9}$

Dukungan nutrisi pada periode perioperatif yang diberikan untuk anak pra, selama, dan pasca operasi dapat menurunkan morbiditas dan mortalitas. ${ }^{10}$ Luka operasi dan stres karena respons operasi besar memerlukan peningkatan kalori untuk energi dan protein untuk sintesis protein. ${ }^{10-11}$ Sekitar 55\%-60\% kebutuhan kalori total tubuh berasal dari karbohidrat. Kepentingan karbohidrat untuk luka sebagai faktor structural lubricants, fungsi transport, imunologi, hormonal, dan ensimatik. Karbohidrat juga menjadi komponen utama glikoprotein dalam penyembuhan luka dan aktivitas ensim heksokinase dan sintase sitrat dalam reaksi penyembuhan luka. Penyediaan energi dari karbohidrat juga dapat melalui penggunaan laktat. Laktat sebagai produk metabolik glukosa penting untuk efek penyembuhan luka. Laktat menstimuli sintesis kolagen dan aktivator penting dalam ekspresi genetik pada jalur penyembuhan selain sebagai penyedia energi. ${ }^{12-18}$

Penyembuhan luka akut maupun kronis juga dapat menggunakan energi dari lemak. Asam lemak, merupakan komponen khusus untuk proliferasi sel luka, inflamasi luka, dan fungsi sel luka. Jadi apabila asupan diet mengandung kadar tinggi monosaturated fatty acid dan omega 3 polyunsaturated fatty acid dapat dikatakan ideal, karena komponen lipid responsibel pada pertumbuhan jaringan dan penyembuhan luka termasuk proses produksi matriks ekstraselular dan kolagen. ${ }^{19-21}$

Protein telah diketahui diperlukan untuk penyembuhan luka dan apabila kekurangan akan menghambat penyembuhan baik luka akut maupun kronik. Aktivitas penyembuhan luka diperankan oleh dipeptida dan polipeptida. Beberapa asam amino seperti glutamin, leusin, arginin juga mempunyai aktivitas anabolik. ${ }^{22}$

Mikronutrien diperlukan sebagai kofaktor dalam sintesis energi dan protein. Apabila kebutuhan energi meningkat, kebutuhan mikronutrien juga meningkat. Variasi jumlah dan peranan mikronutrien yang diperlukan ditentukan oleh besar luka. Vitamin A berfungsi sebagai stimulan awitan proses penyembuhan luka dan epitelisasi serta deposisi fibroblas dari kolagen. Vitamin B kompleks dan vitamin C, yaitu vitamin larut air yang perlu diberikan setiap hari. Glutamin dan arginin adalah komponen lain yang juga diperlukan untuk aktivitas anabolik yaitu memperbaiki sintesis protein. ${ }^{22-25}$ Kelompok trace element yang diperlukan 
pada penyembuhan luka antara lain zinc, copper, dan selenium. Copper diperlukan untuk keseluruhan homeostasis, antioksidan dan untuk collagen and elastin cross-linking. Kebutuhan copper perhari adalah 1-2mg. Mangan (Mn) dapat berfungsi sebagai kofaktor untuk antioksidan superoksida dismutase dan juga aktivitas metaloproteinase pada luka. Kebutuhan untuk maintenans adalah 0,3-0,5 mg perhari. Selenium diperlukan pada sistem glutation untuk antioksi dan intraselular sebagai proteksi sel selama proses penyembuhan luka. Kebutuhan harian untuk terapi luka 100-150 $\mu \mathrm{g}$. Zinc sebagai kofaktor polimerase DNA dan RNA, terlibat dalam sintesis protein dan proliferasi sel. Zinc juga merupakan kofaktor dalam aktivitas matrix metaloproteinase dan terlibat dalam fungsi imun, sintesis kolagen, dismutase superoksida, dan sebagai antioksidan. Pada penyembuhan luka terjadi redistribusi zinc tubuh sesuai berat luka. Keadaan hipermetabolik meningkatkan kehilangan zinc melalui urin, hal tersebut meyebabkan risiko mengalami defisiensi zinc, dan mempengaruhi proses penyembuhan luka dan menurunkan laju epithelisasi, kekuatan kolagen, dan dinding luka. Untuk perbaikan status defisiensi zinc memerlukan pemberian zinc sulfat 4-10 $\mu$ g perhari. Sehingga pada tata laksana penyembuhan luka terdapat indikasi untuk ditambahkan suplemen zinc. ${ }^{24}$

\section{Kesimpulan}

Status gizi buruk, faktor hipoalbumin serta sepsis, berperan hampir seratus persen dalam menimbulkan luka operasi terbuka kembali atau dehiscence pada bedah abdominal mayor pada anak. Sebagai upaya pencegahan adalah meningkatkan kewaspadaan terhadap status gizi kurang dan buruk, anemia, hipoalbumin, dan infeksi berat, serta memberikan dukungan nutrisi yang adekuat. Usulan untuk penelitian yang akan datang adalah skrining dehiscence untuk setiap anak yang akan menjalani operasi bedah mayor

\section{Daftar pustaka}

1. Khan MA. Dehiscence of laparatomy wounds in children. JPMI 2009;23:318-21.

2. Carter RF, Nwomeh B, dan Lanning DA, penyunting. Wound healing. Dalam: Pediatric surgery textbook for
Africa and developing countries. Spectrum book, Ibadan, Nigeria;2011.

3. Keswani SG, Crobleholme TM. Wound Healing: celluler and molecular mechanisms. Dalam: Oldham KT, Colombani PM, Foglia RP, Skinner MA, penyunting. Principles and practice of Pediatric Surgery, Lippincott Williams and Wilkins; 2005 .h.223-38.

4. Ramshorst GH. Risk factor for abdominal wound dehiscence in children: a case-control study. World J Surg 2009;33:150913.

5. Fearon K, Luff R. The nutritional management of surgical patients: enhanced recovery from surgery. Proc Nutr Soc 2003;62:807-11.

6. Waldhausen JHT, Davies L. Pediatric postoperative abdominal wound dehiscence: transverse versus vertical incisions. J Am Col Surg 2000;190:688-91.

7. Çigdem MK, Onen A, Otçu S. Postoperative abdominal evisceration in children: possible risk factors. Pediatr Surg Int 2006;22:677-80.

8. Cohendy R, Gros F, Tran J. Preoperative nutritional evaluation of elderly patients: the Mini Nutritional Assessment as a practical tool. Clin Nutr 1999;18: 3458.

9. Miller S, Wolf RR. The dangers of weight loss in the elderly. J Nutr Health Aging 2008;12:487-91.

10. Wilmore DW. Metabolic response to severe surgical illness: overview. World J Surg 2000;24:705-11.

11. Gaillard C, Alix E, Boirie Y. Are elderly hospitalized patients getting enough protein? J Am Geriatr Soc. 2008;56:1045-9.

12. Wilson J, Cdark J. Advances in skin and wound care. J Rev Wound Healing 2004; 17:426.

13. Patel G. The role of nutrition in managing lower extremity wounds. Int J Low Extrem Wounds 2005;4:1222.

14. Williams J, Barbul A. Nutrition and wound healing. Surg Clin North Am 2003;83:S71-S96.

15. Rodriguez-Key M, Alonzi A. Nutrition skin integrity, and pressure ulcer healing in chronically ill children: an overview. Ostomy Wound Manage 2007;53:56-8.

16. Borsheim E, Bui Q, Tissier S. Effect of amino acid supplementation on muscle mass, strength and physical function in elderly. Clin Nutr 2008;27:189-95.

17. Ord H. Nutritional support for patients with infected wounds. Br J Nurs. 2007;16:1346-8.

18. Irelton-Jones C, Liepa R. Carbohydrates and wound healing in nutrition. Dalam: Molner J, penyunting. Nutrition and Wound Healing. Boca Raton, Fla: CRC press; 2006.h.5. 
19. Mori R, Kondo T, Nishie T. Impairment of skin wound healing in $\beta$ 1,4 galactosyltransferase deficient mice with leukocyte recruitment. Am J Pathol 2004;164:1303-14.

20. Hunt T. Lactate modulates gene expression of human mesenchymal stem cells. Langenbecks Arch Surg 2008;393:297-301.

21. Hunt T, Aslam R, Beckert S. Aerobically generated lactate stimulates angiogenesis and tissue repair via redox mechanisms. Antioxid Redox Signal 2007;9:1115-24.

22. Güven A, Pehlivan M, Gökpinar I, Gürleyik E, Cam M. Early glutamine-enriched enteral feeding facilitates colonic anastomosis healing: light microscopic and immunohistochemical evaluation. Acta Histochem
2007;109:122-9.

23. Ahuja V, Rizk M, Barbul A. Dalam: Molnar J, penyunting. Arginine and Wound Healing in Nutrition and Wound Healing. New York, NY: CRC Press; 2007.h.87.

24. Desneves K, Todorovic B, Cassar A, Crowe T. Treatment with supplementary arginine, vitamine $\mathrm{C}$ and zinc in patients with pressure ulcers: a randomized controlled trial. Clin Nutr 2005;24:979-87.

25. Wischmeyer P, Lynch J, Liedel J. Glutamine administration reduces Gram-negative bacteremia in severely burned patients: a prospective, randomized, doubleblind trial versus isonitrogenous control. Crit Care Med 2001;29:2075-80. 